\title{
Analisis Pengaruh Harga Emas, Harga Minyak Dunia, Dan Kurs Terhadap Harga Saham Sektoral BEI Sebelum Dan Sesudah Merebaknya Covid-19 Di Indonesia Menggunakan VECM
}

\author{
(Analysis of the Effect of Gold Prices, World Oil Prices, and Exchange Rates on IDX Sectoral Stock \\ Prices Before and After the Outbreak of Covid-19 in Indonesia Using VECM) \\ Asrif' $^{1 *}{ }^{1 *}$, Wahyudin ${ }^{2}$ \\ 1,2 Politeknik Statistika STIS \\ Jalan Pandega E No. 104 RT.04/07, Kota Bekasi, Jawa Barat \\ E-mail: 211709578@stis.ac.id
}

\begin{abstract}
ABSTRAK
Penelitian ini bertujuan untuk menganalisis pengaruh harga emas, harga minyak dunia, dan nilai kurs rupiah terhadap harga saham sektoral BEI pada saat sebelum dan sesudah merebaknya pandemi Covid-19 di Indonesia. Data penelitian ini menggunakan data sekunder berupa data mingguan harga emas, harga minyak Brent, dan kurs rupiah terhadap dolar AS, serta variabel dummy periode sebelum dan sesudah pandemi Covid 19 di Indonesia sebagai variabel eksogen. Analisis dilakukan dengan menerapkan metode analisis Vector Error Correction Model (VECM). Hasil penelitian menunjukkan bahwa dalam jangka panjang harga emas berpengaruh signifikan bagi saham sektor industri dasar dan kimia, sektor aneka industri, sektor properti, dan sektor keuangan, variabel harga minyak dunia berpengaruh signifikan bagi saham sektor pertanian, sektor industri dasar dan kimia, dan sektor aneka industri, dan variabel kurs rupiah berpengaruh signifikan bagi saham sektor aneka industri, sektor infrastruktur, dan sektor keuangan. Sedangkan, dalam jangka pendek, harga emas berpengaruh signifikan bagi seluruh harga saham sektoral, kecuali sektor pertanian, variabel harga minyak dunia berpengaruh signifikan bagi saham sektor pertanian, sektor aneka industri, dan sektor keuangan, variabel kurs rupiah hanya berpengaruh bagi harga saham sektor pertanian, dan adanya pandemi Covid-19 di Indonesia membuat seluruh harga saham sektoral BEI menjadi lebih rendah.
\end{abstract}

Kata kunci: VECM, Harga Saham Sektoral, Emas, Minyak, Kurs

\begin{abstract}
This study aims to analyze the effect of gold price, oil price, and exchange rate on IDX sectoral stock prices before and after the outbreak of Covid-19 in Indonesia. The data was collected from secondary data in the form of weekly data on gold prices, Brent oil prices, and exchange rate, and dummy variables for the period before and after the outbreak of the Covid 19 in Indonesia as exogenous variables. The analysis was carried out by applying the Vector Error Correction Model (VECM) analysis method. The results show that in the long term the gold price has a significant effect on stock prices of the basic and chemical industrial sector, the miscellaneous industrial sector, the property sector, and the financial sector, the world oil price has a significant effect on stock prices of the agricultural sector, basic and chemical industrial sector, and the miscellaneous industrial sector, and the exchange rate variable has a significant effect on stock prices of the miscellaneous industrial sector, the infrastructure sector, and the financial sector. Meanwhile, in the short term, the gold price has a significant effect on all sectoral stock prices, except for the agricultural sector, the world oil price variable has a significant effect on stock prices of the agricultural sector, the miscellaneous industrial sector, and the financial sector, the exchange rate variable only has a significant effect on stock prices of the agricultural sector, and the outbreak of Covid-19 in Indonesia caused all IDX sectoral stock prices to be lower.
\end{abstract}

Keywords: VECM, Sectoral Stock Prices, Gold, Oil, Exchange Rate

\section{PENDAHULUAN}

Pandemi Covid-19 merupakan sebuah epidemi penyakit yang disebabkan oleh Coronavirus yang telah menyebar ke berbagai negara hampir di seluruh dunia, tidak terkecuali di Indonesia. Dilansir dari situs web covid19.go.id, dalam kurun waktu 8 bulan sejak 2 Maret 2020 diumumkannya kasus pertama pasien Covid19, kasus positif Covid-19 di Indonesia telah mencapai angka 415.402 kasus. Peristiwa pandemi tersebut menyebar dengan cepat ke berbagai daerah di Indonesia dan telah banyak mengubah tatanan kehidupan serta berdampak banyak terhadap berbagai bidang termasuk bidang ekonomi. Hal ini terbukti dengan adanya kontraksi pertumbuhan ekonomi di Indonesia (y-y) yang terjadi pada triwulan-II 2020 sebesar $-5,32 \%$ (BRS BPS, 2020). Selain itu, lumpuhnya sektor pariwisata dan penurunan produktivitas pada sektor lainnya sebagai imbas dari adanya penerapan Pembatasan Sosial Berskala Besar (PSBB) di berbagai daerah di Indonesia juga 
mengakibatkan terjadinya penurunan kegiatan investasi. Kegiatan investasi baik investasi yang berasal dari dalam negeri maupun luar negeri mengalami penurunan drastis karena ketidakpastian yang tinggi dan kondisi bisnis yang tidak kondusif efek dari merebaknya pandemi Covid-19 di Indonesia.

Pasar modal merupakan sarana pendanaan dan sarana berinvestasi bagi perusahaan dan institusi lain dengan cara memberikan kesempatan bagi masyarakat untuk berpartisipasi dalam menunjang pembiayaan perekonomian nasional. Terlebih pada saat pandemi seperti saat ini, dimana seluruh perekonomian dunia mengalami kelumpuhan sehingga peranan pasar modal sebagai salah satu alternatif pembiayaan dan investasi sangat dibutuhkan untuk memulihkan ekonomi Indonesia akibat pandemi Covid-19. Banyaknya kegiatan atau besarnya volume penjualan dan pembelian di pasar modal dapat dijadikan dasar dalam penentuan harga saham. Apabila dilihat secara agregat, hal ini juga dapat dijadikan sebagai salah satu indikator perekonomian negara. Salah satu indikator yang sering digunakan untuk melihat perkembangan pasar modal adalah Indeks Harga Saham Gabungan (IHSG). Berbeda dengan indeks saham lain yang memberikan gambaran keadaan harga saham secara khusus untuk kelompok perusahaan tertentu, IHSG merupakan cerminan kinerja saham-saham seluruh perusahaan yang terdaftar di BEI (Pradhypta, 2018).

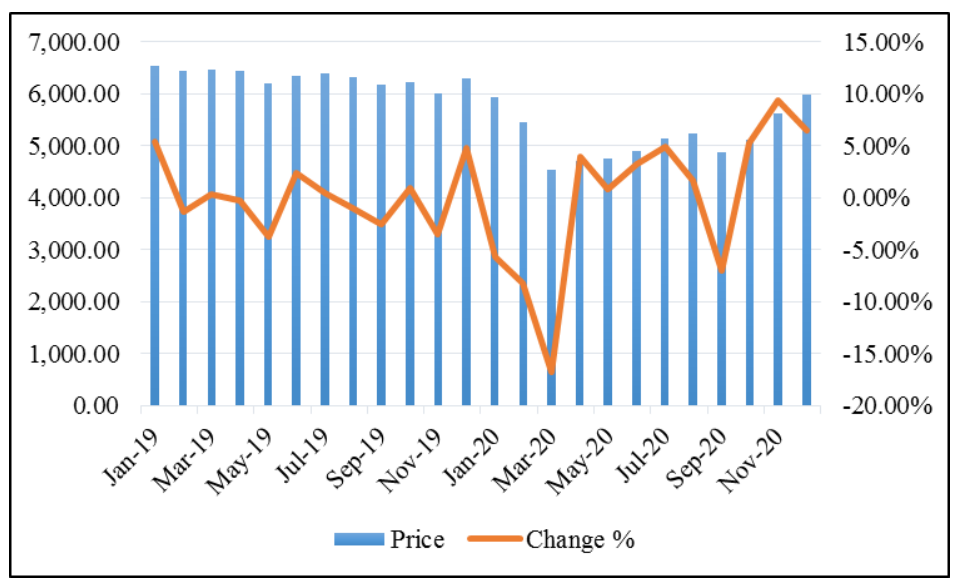

Gambar 1. Perkembangan IHSG 2019-2020

Selama tahun 2019 hingga 2020, harga saham gabungan yang terdapat pada BEI mengalami fluktuasi. Sejak bulan Januari 2019 hingga Desember 2019, harga saham gabungan cenderung konstan berada di tingkat harga yang sama, yakni kisaran level di atas 6.000 IDR. Namun, pada Januari 2020 hingga Maret 2020 mengalami penurunan yang tajam dengan besaran harga saham lebih rendah dibandingkan pada bulan-bulan sebelumnya di tahun 2019 dan persentase perubahannya pun berangsur-angsur mengalami kontraksi hingga tingkat terendah terjadi pada bulan Maret 2020 yakni sebesar -16.76 persen. Kemudian, pada bulan April 2020 hingga Desember 2020 harga saham gabungan perlahan-lahan cenderung mengalami peningkatan, hanya saja pada bulan September 2020 sempat mengalami penurunan.

Bursa Efek Indonesia membagi seluruh emiten yang terdaftar ke dalam sembilan saham sektoral yakni sektor pertanian (JKAGRI), sektor pertambangan (JKMING), sektor industri dasar dan kimia (JKBIND), sektor aneka industri (JKMISC), sektor industri barang konsumsi (JKCONS), sektor properti, real estate, dan konstruksi bangunan (JKPROP), sektor infrastruktur, utilitas, dan transportasi (JKINFA), sektor keuangan (JKFINA), dan sektor perdagangan, jasa, dan investasi (JKTRAD). Meskipun hampir seluruh saham sektoral terdampak oleh pandemi ini, tetapi dampaknya terhadap saham sektoral tersebut berbeda-beda. Bagi sebagian besar saham sektoral tidak mampu bertahan di tengah kondisi saat ini terutama yang berperan di bidang pariwisata yakni sektor perdagangan, jasa, dan investasi. Namun, ada pula beberapa saham sektoral yang defensif menghadapi pandemi saat ini yakni sektor industri dasar dan kimia, sektor industri barang konsumsi, dan sektor keuangan, terutama sub sektor perbankan (Fawzi, 2020).

Tiap-tiap harga saham sektoral mungkin dipengaruhi oleh berbagai faktor yang berbeda-beda dan bisa saja bagi beberapa saham sektoral pandemi Covid-19 belum tentu berpengaruh signifikan. Adapun kondisi makroekonomi merupakan faktor dominan yang berpengaruh dalam pergerakan harga saham. Kondisi makroekonomi merupakan determinan penting bagi harga saham di semua pasar modal dan mempunyai pengaruh yang dominan terhadap pergerakan harga saham (Sirucek, 2012). Tidak hanya kondisi makroekonomi di dalam negeri, tetapi kondisi perekomian dunia juga perlu dipertimbangkan karena kini perekonomian dunia semakin terintegrasi oleh aktivitas perdagangan antarnegara maupun tuntutan globalisasi (Sofyani \& Wahyudi, 2015). 
Banyak indikator makroekonomi yang memiliki pengaruh terhadap fluktuasi harga saham diantaranya adalah faktor global, misalnya harga emas dan harga minyak dunia serta faktor dalam negeri, misalnya nilai tukar atau kurs. Penelitian yang dilakukan oleh Witjaksono (2010) menunjukkan bahwa harga emas dan harga minyak dunia berpengaruh positif terhadap IHSG, tetapi nilai kurs rupiah terhadap dolar berpengaruh negatif terhadap IHSG. Namun, terdapat beberapa penelitian lain yang menunjukkan hasil berbeda seperti penelitian yang dilakukan oleh Kurniawan (2013) yang menunjukkan bahwa harga minyak dunia justru tidak berpengaruh terhadap IHSG dan penelitian yang dilakukan oleh Pradhypta (2018) menunjukkan hasil bahwa nilai kurs rupiah justru berpengaruh positif terhadap IHSG.

Pandemi Covid-19 memberikan dampak yang besar terhadap perekonomian di Indonesia khususnya pasar modal. Hal ini terbukti dari terjadinya penurunan secara massal kontribusi produksi dari berbagai sektor lapangan usaha terhadap PDB Indonesia. Beberapa sektor lapangan usaha yang mengalami kontraksi pertumbuhan tertinggi adalah sektor transportasi dan pergudangan yang mencapai $-30,84$ persen dan sektor penyediaan akomodasi dan makan minum sebesar -22,02 persen (BRS BPS, 2020). Beberapa penelitian yang telah dilakukan pun hanya menggunakan harga saham agregat (IHSG) bukan dilihat secara sektoral dan memberikan hasil kesimpulan yang cenderung tidak konsisten atau berbeda antara satu peneliti dengan peneliti lainnya. Dengan adanya ketidakkonsistenan hasil penelitian tersebut dan kondisi makroekonomi baik di dalam negeri maupun global yang dinamis atau terus mengalami perubahan dari waktu ke waktu, maka peneliti tertarik untuk melakukan penelitian terkait pengaruh harga emas, harga minyak dunia, dan nilai kurs terhadap harga saham sektoral BEI pada saat sebelum dan sesudah merebaknya pandemi Covid-19 di Indonesia dengan memperhatikan hubungan kointegrasi yang terjadi melalui penggunaan metode VECM.

Tujuan yang hendak dicapai dari penelitian ini adalah sebagai berikut.

1. Mengetahui perkembangan harga saham sektoral BEI pada saat sebelum dan sesudah adanya pandemi Covid-19.

2. Menganalisis pengaruh harga emas, harga minyak dunia, kurs rupiah, serta periode sebelum dan sesudah merebaknya pandemi Covid-19 di Indonesia terhadap harga saham sektoral BEI dengan menggunakan metode VECM.

3. Mengetahui apakah penggunaan VECM tepat digunakan untuk meneliti harga saham sektoral BEI.

\section{METODE}

\section{Data dan Sumber Data}

Cakupan penelitian ini meliputi saham sektoral BEI dengan variabel independen yang digunakan terdiri dari harga emas, harga minyak dunia Brent, nilai tukar (kurs) rupiah terhadap dolar, serta periode sebelum dan sesudah merebaknya pandemi Covid-19 di Indonesia. Sementara itu, variabel dependen yang digunakan pada penelitian ini adalah harga saham sektoral BEI. Sektor-sektor tersebut akan dianalisis secara individu (masingmasing) dengan menggunakan metode analisis yang sama. Periode waktu penelitian yakni sejak Juni 2019 hingga November 2020 dengan intervalnya berupa mingguan sehingga data yang diambil merupakan data tiap akhir minggu. Penelitian ini menggunakan data sekunder yang diperoleh dari situs web investing.com. Penjelasan terkait karakteristik setiap variabel data yang dikumpulkan adalah sebagai berikut.

1. Harga saham sektoral merupakan harga rata-rata mingguan pada harga penutupan saham yang didasarkan menurut klasifikasi JASICA (Jakarta Stock Classification Index) dengan satuan mata uang dalam IDR. Pengklasifikasian berdasarkan JASICA dilakukan menurut aktivitas ekonomi utama perusahaan emiten dan berguna sebagai indikator kinerja untuk setiap kelompok industri yang terbagi ke dalam sembilan sektor.

2. Harga emas merupakan harga rata-rata mingguan pada harga penutupan dengan satuan dalam USD per 1 troy ons.

3. Harga minyak mentah Brent merupakan harga rata-rata mingguan pada harga penutupan dengan satuan mata uang dalam USD per 1 barel.

4. Nilai tukar (kurs) rupiah terhadap dolar merupakan harga rata-rata mingguan pada harga penutupan dengan satuan mata uang dalam IDR per 1 USD.

5. Periode sebelum dan sesudah merebaknya pandemi Covid-19 di Indonesia merupakan variabel dummy dengan nilai 0 untuk periode sebelum merebaknya pandemi Covid-19 di Indonesia dan nilai 1 untuk periode setelahnya. 


\section{Metode Analisis}

Analisis yang digunakan pada penelitian ini yakni analisis deskriptif dan inferensia. Analisis deskriptif digunakan untuk menjawab poin pertama pada tujuan penelitian, sedangkan analisis inferensia digunakan untuk menjawab poin kedua dan ketiga pada tujuan penelitian. Pada analisis inferensia diterapkan pendekatan metode Vector Error Correction Model (VECM) untuk mengatasi masalah kestasioneran data dan kointegrasi yang terjadi antar variabel dalam sistem dengan menggunakan software Eviews 10. Berikut ini adalah tahapan pembentukan model VECM antara lain sebagai berikut.

1. Uji Kestasioneran Data

Pemeriksaan kestasioneran data pada level dilakukan dengan pengujian secara statistik menggunakan uji Augmented Dickey-Fuller (ADF test). Apabila data sudah stasioner, maka model VAR in level form dapat langsung dirumuskan dan diestimasi. Tetapi, apabila data tidak/belum stasioner, maka terdapat dua kemungkinan model yang dapat digunakan, yaitu (1) dengan melakukan differencing terhadap data sehingga data menjadi stasioner dan modelnya menjadi VAR in difference form atau (2) tidak melakukan differencing namun merestriksi VAR dengan persamaan kointegrasi sehingga modelnya menjadi model VECM (Juanda \& Junaidi, 2012: 146). Dari pengujian ADF test diperoleh hasil bahwa seluruh variabel penelitian tidak stasioner pada level, tetapi stasioner pada first difference.

2. Penentuan Lag Optimum

3. Pengujian Kestabilan Sistem VAR melalui nilai inverse root of Auto Regressive (AR) karakteristik polinomialnya.

4. Pengujian Kointegrasi dengan pendekatan Johansen test.

5. Pemodelan VECM

Pemodelan VECM digunakan untuk mengidentifikasi hubungan jangka pendek dan jangka panjang pada variabel-variabel penelitian. Adapun spesifikasi model VECM pada penelitian ini diilustrasikan melalui persamaan 1.

$$
\begin{gathered}
\Delta \text { Sektor }_{i t}=\beta_{i 0}+\lambda_{i} \text { EC }_{i t-1}+\sum_{j=1}^{p} \beta_{i j} \Delta \text { Sektor }_{i t-j}+\sum_{k=1}^{p} \beta_{i k} \Delta \text { Emas }_{t-k}+ \\
\sum_{l=1}^{p} \beta_{i l} \Delta \text { Minyak }_{t-l}+\sum_{m=1}^{p} \beta_{i m} \Delta \text { Kurs }_{t-m}+\alpha_{i} \text { Dummy }+\varepsilon_{i t}
\end{gathered}
$$

dimana:

$p=$ panjang lag

$\Delta=$ operator yang menunjukkan diferensiasi pertama (first difference)

$E C_{t-1}=$ error correction term lag 1 dengan koefisien sebesar $\lambda$ (speed of adjustment) yang dapat diinterpretasikan sebagai kesalahan keseimbangan dari periode waktu sebelumnya (t-1). Adanya kointegrasi ditunjukkan melalui koefisien $\lambda$ yang bernilai negatif dan signifikan.

$\lambda=$ speed of adjustment atau koefisien yang menggambarkan ukuran kecepatan koreksi ketidakseimbangan jangka pendek menuju keseimbangan jangka panjang. Di mana sekitar $\lambda^{*} 100 \%$ penyesuaian tersebut akan terjadi pada periode pertama berikutnya dan sisanya pada periode-periode selanjutnya.

$\alpha_{i}=$ koefisien yang menunjukkan pengaruh adanya pandemi Covid-19 terhadap harga saham sektor ke-i

6. Pengujian Uji Wald

7. Uji Asumsi Klasik

Pengujian asumsi klasik bertujuan untuk menghasilkan estimator yang bersifat BLUE (Best Linear Unbiased Estimator) dan layak untuk diinterpretasikan. Dalam penelitian ini dilakukan pengujian asumsi klasik pada model VECM yang telah terbentuk. Pengujian asumsi klasik yang dilakukan terdiri dari uji autokorelasi, uji heteroskedastisitas, dan uji normalitas.

\section{HASIL DAN PEMBAHASAN}

\section{Gambaran Umum Perkembangan Harga Saham Sektoral}

Secara umum, pergerakan harga saham sektoral BEI mengalami fluktuasi yang tajam pada saat sebelum dan sesudah merebaknya pandemi Covid-19 di Indonesia. Selama sebelum adanya pandemi Covid-19 harga saham sektoral mingguan BEI cenderung konstan pada level yang sama untuk setiap sektornya. Pada triwulan II-2019 hingga triwulan IV-2019 harga saham mingguan sektor pertanian cenderung konstan pada level 1.400 IDR. Hal serupa juga terjadi pada beberapa harga saham sektor lain diantaranya adalah harga saham sektor aneka industri, sektor infrastruktur, sektor keuangan, dan sektor perdagangan yang cenderung konstan kisaran level 1.200-1.300 IDR, dan harga saham sektor properti yang konstan kisaran level 450-500 IDR. Sedangkan, kondisi berbeda terjadi pada harga saham sektor industri barang konsumsi dan harga saham sektor pertambangan yang justru mengalami penurunan sejak pertengahan triwulan III-2019. Berbeda dengan saham 
sektoral lainnya, harga saham sektor industri dasar dan kimia merupakan satu-satunya harga saham sektoral BEI yang justru mengalami pertumbuhan positif yang masif sejak awal tahun 2019.

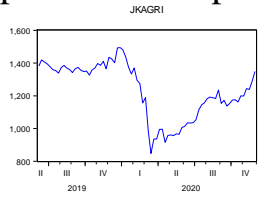

skmisc

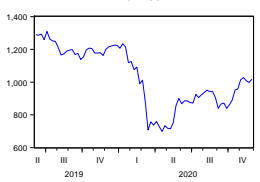

JKNFA

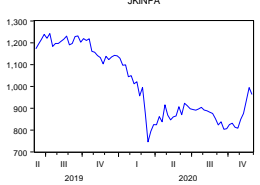

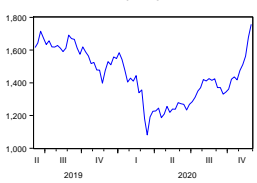

Jkcons

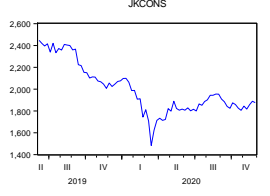

JKFNA

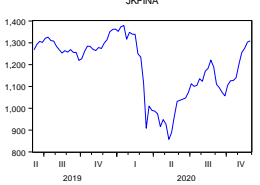

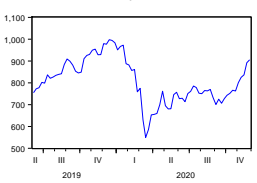

נкрнов
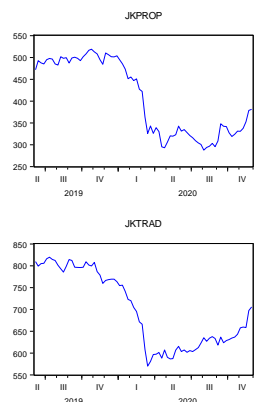

Gambar 2. Perkembangan IHSG 2019-2020

Kemudian sejak awal triwulan I-2020, secara umum, pergerakan harga saham sektoral BEI cenderung mengalami penurunan. Pergerakan harga saham sektoral terus mengalami penurunan hingga puncak terendahnya terjadi pada akhir triwulan I-2020 yakni bulan Maret 2020. Harga saham mingguan sebagian besar sektor di BEI anjlok hingga mencapai level terendahnya terjadi pada minggu yang sama yakni 15 Maret 2020, diantaranya adalah harga saham mingguan sektor pertanian terendah di level 847,85 IDR, sektor pertambangan terendah di level 1.080,81 IDR, sektor industri dasar dan kimia terendah di level 549,34 IDR, sektor industri barang konsumsi terendah di level 1.482,90 IDR, sektor infrastruktur terendah di level 745,82, dan sektor perdagangan terendah di level 569,88 IDR. Sedangkan, harga saham mingguan sektor aneka industri mengalami penurunan lebih lambat hingga pada satu bulan berikutnya yakni 19 April 2020 dengan level terendahnya sebesar 698,51 IDR. Hal serupa juga terjadi pada harga saham mingguan sektor keuangan yang mengalami penurunan lebih lambat hingga pada dua bulan berikutnya yakni 10 Mei 2020 dengan level terendahnya sebesar 856,98 IDR. Bahkan, harga saham mingguan sektor properti merupakan sektor saham yang mengalami penurunan paling lambat dibandingkan sektor lainnya yakni mencapai level terendahnya pada 02 Agustus 2020 sebesar 287,7 IDR. Namun, setelah harga saham sektoral BEI mengalami penurunan yang drastis, berangsur-angsur harga saham sektoral BEI kembali meningkat hingga November 2020.

\section{Estimasi Pemodelan VECM Pada Saham Sektoral}

Setelah melakukan tahapan pengujian kestasioneran data hingga penentuan lag optimum diperoleh hasil lag optimum terpilih dan memenuhi pengujian kestabilan dalam sistem VAR. Kemudian, dilakukan pengujian kointegrasi melalui pendekatan Johansen test yang menyimpulkan bahwa terdapat hubungan jangka panjang antara variabel dalam sistem. Berikut ini adalah pengujian keberartian parameter dan ketepatan model dari persamaan VECM saham sektoral:

Tabel 1. Keberartian parameter dan ketepatan model

\begin{tabular}{ccccc}
\hline No. & Saham Sektoral & Prob. F-Statistik & $\mathrm{R}^{2}$ & Durbin Watson \\
\hline 1 & JKAGRI & $0,077507^{*}$ & 0,489150 & 1,660200 \\
2 & JKMING & 0,594516 & 0,349464 & 1,744405 \\
3 & JKBIND & $0,001762^{*}$ & 0,677148 & 1,782394 \\
4 & JKMISC & $0,000065^{*}$ & 0,686493 & 1,832480 \\
5 & JKCONS & $0,027496^{*}$ & 0,531623 & 2,111053 \\
6 & JKPROP & $0,002246^{*}$ & 0,608819 & 1,707801 \\
7 & JKINFA & $0,003331^{*}$ & 0,533276 & 1,711458 \\
8 & JKFINA & $0,000094^{*}$ & 0,679378 & 1,692338 \\
9 & JKTRAD & 0,121019 & 0,467554 & 2,021173 \\
\hline
\end{tabular}

Berdasarkan tabel 1 menunjukkan bahwa dari kesembilan sektor, ditemukan bahwa terdapat dua sektor yang memiliki probabilitas F-statistik yang tidak signifikan (alpha 5\% dan 10\%) yakni sektor pertambangan, dan sektor perdagangan, jasa, dan investasi. Dari hasil tersebut dapat disimpulkan bahwa secara simultan, tidak 
terdapat variabel-variabel pada model persamaan VECM yang berpengaruh terhadap perubahan dari kedua saham sektor tersebut (sektor pertambangan dan sektor perdagangan, jasa, dan investasi) atau dengan kata lain dapat dikatakan bahwa dengan tingkat signifikansi sebesar 5 persen dapat disimpulkan bahwa secara bersamasama keseluruhan koefisien pada model bernilai nol atau model yang terbentuk tidak fit bagi kedua saham sektoral tersebut. Oleh karena itu, analisis VECM untuk kedua harga saham sektoral tersebut tidak dapat dilanjutkan pada tahapan berikutnya.

Sedangkan untuk mengetahui ada tidaknya spurious regression dari model persamaan tertentu dapat diindikasikan melalui nilai $\mathrm{R}^{2}$ yang dibandingkan terhadap nilai Durbin Watson. Nilai $\mathrm{R}^{2}$ yang lebih kecil dibandingkan nilai Durbin Watson menunjukkan bahwa tidak terjadi spurious regression (regresi semu). Dari tabel 1 dapat diketahui bahwa untuk keseluruhan persamaan saham sektoral BEI diperoleh hasil bahwa nilai $\mathrm{R}^{2}$ yang dihasilkan lebih kecil dari nilai Durbin Watson yang menunjukkan bahwa tidak ada spurious regression untuk tiap-tiap persamaan.

\section{Pengaruh Harga Emas, Harga Minyak Dunia, Dan Kurs IDR/USD Pada Harga Saham Sektoral Dalam Jangka Panjang}

Tabel 2. Persamaan VECM jangka panjang pada setiap harga saham sektoral

\begin{tabular}{cccccc}
\hline \multirow{2}{*}{ No. } & \multirow{2}{*}{ Saham Sektoral } & \multirow{2}{*}{ ECT } & Jangka Panjang \\
\cline { 4 - 6 } & & & Harga Emas & Harga Minyak & Kurs \\
\hline 1 & JKAGRI & $0,437229^{*}$ & $-0,229792$ & $1,063033^{*}$ & 0,176062 \\
2 & JKBIND & $0,246500^{*}$ & $-1,054110^{*}$ & $1,055697^{*}$ & $-2,215817$ \\
3 & JKMISC & $0,008672^{*}$ & $-41,32783^{*}$ & $19,65161^{*}$ & $-134,0717^{*}$ \\
4 & JKCONS & 0,046069 & $-2,308078^{*}$ & $2,437296^{*}$ & $5,448782^{*}$ \\
5 & JKPROP & $-0,455138^{*}$ & $-0,854023^{*}$ & 0,167165 & $-0,003621$ \\
6 & JKINFA & $-0,166530^{*}$ & 0,388997 & 0,021732 & $4,447537^{*}$ \\
7 & JKFINA & $-0,100178^{*}$ & $1,351671^{*}$ & $-0,583838$ & $6,813800^{*}$ \\
\hline
\end{tabular}

Berdasarkan tabel 2 diperoleh hasil bahwa dari ke tujuh saham sektoral, terdapat 1 sektor yg memiliki nilai ECT yang tidak signifikan yakni saham sektor industri barang konsumsi. Nilai koefisien ECT yang tidak signifikan menunjukkan bahwa tidak terdapat hubungan jangka panjang antar variabel dalam model persamaan VECM saham sektor industri barang konsumsi (JKCONS). Sedangkan, sektor pertanian (JKAGRI), sektor industri dasar dan kimia (JKBIND) dan sektor aneka industri (JKMISC) memiliki ECT yang bernilai positif signifikan. Nilai ECT yang bernilai signifikan menunjukkan bahwa ketidakseimbangan yg terjadi pada jangka pendek justru melebar atau divergen (tidak menuju keseimbangan). Dari tabel 2 juga dapat diketahui bahwa hanya 3 saham sektoral yang memiliki hubungan keseimbangan jangka panjang yang ditandai dengan nilai koefisien ECT yang negatif signifikan yakni sektor properti, real estate, dan konstruksi bangunan (JKPROP), sektor infrastruktur, utilitas, dan transportasi (JKINFA), dan sektor keuangan (JKFINA).

Kemudian dalam jangka panjang variabel harga emas berpengaruh pada hampir seluruh saham sektoral kecuali sektor pertanian (JKAGRI) dan sektor infrastruktur, utilitas, dan transportasi (JKINFA). Variabel harga minyak dunia berpengaruh pada sektor pertanian (JKAGRI), sektor industri dasar dan kimia (JKBIND), dan sektor aneka industri (JKMISC). Sedangkan, variabel nilai kurs berpengaruh pada sektor aneka industri (JKMISC), sektor infrastruktur, utilitas, dan transportasi (JKINFA), dan sektor keuangan (JKFINA).

\section{Pengaruh Harga Emas, Harga Minyak Dunia, Dan Kurs IDR/USD Pada Harga Saham Sektoral Dalam Jangka Pendek}

Tabel 3. Persamaan VECM jangka pendek pada setiap harga saham sektoral

\begin{tabular}{|c|c|c|c|c|c|c|}
\hline \multirow{2}{*}{ No. } & \multirow{2}{*}{$\begin{array}{l}\text { Saham } \\
\text { Sektoral }\end{array}$} & \multirow{2}{*}{ Dummy } & \multicolumn{3}{|c|}{ Jangka Pendek } & \multirow{2}{*}{ MAPE } \\
\hline & & & Harga Emas & Harga Minyak & Kurs & \\
\hline 1 & JKAGRI & $-0,122064 *$ & Tidak signifikan & Signifikan & Signifikan & 1,497710 \\
\hline 2 & JKBIND & $-0,120298^{*}$ & Signifikan & Tidak signifikan & Tidak signfikan & 9,242709 \\
\hline 3 & JKMISC & $-0,188446^{*}$ & Signifikan & Signifikan & Tidak signifikan & 0,594016 \\
\hline 4 & JKPROP & $-0,082406^{*}$ & Signifikan & Tidak signifikan & Tidak signifikan & 1,353297 \\
\hline 5 & JKINFA & $-0,088877 *$ & Signifikan & Tidak signifikan & Tidak signifikan & 0,840879 \\
\hline 6 & JKFINA & $-0,095234^{*}$ & Signifikan & Signifikan & Tidak signifikan & 0,630430 \\
\hline
\end{tabular}


Berdasarkan tabel 3 dapat diketahui bahwa dalam jangka pendek perbedaan kondisi sebelum dan sesudah merebaknya pandemi Covid-19 yang diproksikan dengan variabel dummy memberikan pengaruh negatif signifikan bagi seluruh saham sektoral. Hal ini menunjukkan bahwa adanya pandemi Covid-19 di Indonesia menurunkan seluruh harga saham sektoral BEI. Dalam jangka pendek, variabel harga emas berpengaruh signifikan terhadap seluruh saham sektoral BEI kecuali sektor pertanian (JKAGRI). Sedangkan, variabel harga minyak dunia hanya berpengaruh signifikan terhadap saham sektor pertanian (JKAGRI), sektor aneka industri (JKMISC), dan sektor keuangan (JKFINA). Sementara itu, variabel nilai kurs tidak berpengaruh terhadap hampir seluruh saham sektoral kecuali sektor pertanian (JKAGRI).

Berdasarkan tabel 3 dapat diketahui bahwa keseluruhan persamaan VECM pada tiap saham sektoral BEI mempunyai nilai MAPE dibawah 10\%. Pemeriksaan validitas dari model dilakukan dengan menghitung Mean Absolute Prediction Error (MAPE). MAPE adalah rata-rata dari jumlah semua persentase kesalahan untuk kumpulan data tertentu yang diambil tanpa memperhatikan tanda. Nilai MAPE dalam satuan persen dapat memberikan informasi persentase kesalahan yang tergolong tinggi, sedang, atau rendah. Menurut Lewis (1982) dalam Moreno et al. (2013), MAPE yang bernilai kurang dari 10\% menunjukkan peramalan yang sangat akurat. Hal ini menunjukkan bahwa pemodelan VECM pada tiap saham sektoral memiliki akurasi yang tinggi dalam memprediksi variabel harga saham sektoral. Di antara ke enam saham sektoral tersebut, sektor aneka industri mempunyai nilai MAPE paling rendah, yakni sebesar 0,594\%. Kemudian diikuti dengan nilai MAPE saham sektor keuangan sebesar $0,630 \%$, sektor infrastruktur, utilitas, dan transportasi sebesar $0,840 \%$, sektor properti, real estate, dan konstruksi bangunan sebesar 1,353\%, dan sektor pertanian sebesar 1,497\%. Sedangkan, saham sektor industri dasar dan kimia memiliki nilai MAPE yang rentangnya jauh dibandingkan sektor lainnya, yakni sebesar 9,2427\%.

\section{Pengujian Asumsi Klasik}

Tabel 4. Hasil pengujian asumsi klasik

\begin{tabular}{ccccc}
\hline No. & Saham Sektoral & Uji Nonautokorelasi & Uji Homoskedastisitas & Uji Normalitas \\
\hline 1 & JKAGRI & Tidak terlanggar & 0,7004 & 0,0028 (Terlanggar) \\
2 & JKBIND & Tidak terlanggar & 0,6624 & 0,7793 \\
3 & JKMISC & Tidak terlanggar & 0,1277 & 0,5540 \\
4 & JKPROP & Tidak terlanggar & 0,4152 & 0,9866 \\
5 & JKINFA & Tidak terlanggar & 0,4295 & 0,3188 \\
6 & JKFINA & Tidak terlanggar & 0,2288 & 0,7743 \\
\hline
\end{tabular}

Pengujian asumsi klasik nonautokorelasi pada penelitian ini dilakukan dengan memanfaatkan uji Portmanteau residual. Berdasarkan tabel 4 diperoleh hasil bahwa dengan tingkat signifikansi sebesar $\alpha=5 \%$ tidak terdapat autokorelasi residual atau memenuhi asumsi white noise untuk seluruh persamaan VECM harga saham sektoral. Pengujian asumsi klasik homoskedastisitas dilakukan dengan memanfaatkan uji White, dengan hipotesis nol varians konstan atau tidak terjadi masalah heteroskedastisitas. Dari tabel 4 didapatkan hasil bahwa keseluruhan persamaan VECM harga saham sektoral memiliki p-value lebih dari $\alpha=5 \%$ atau dengan kata lain gagal tolak $\mathrm{H}_{0}$, sehingga dapat disimpulkan bahwa dengan tingkat signifikansi sebesar $\alpha=5 \%$ tidak terdapat masalah heteroskedastisitas untuk seluruh persamaan harga saham sektoral. Pengujian asumsi klasik normalitas pada penelitian ini dilakukan dengan memanfaatkan uji Jarque-Bera dengan hipotesis nol error mengikuti distribusi normal multivariate. Berdasarkan tabel 4 dapat diketahui bahwa persamaan VECM harga saham sektor pertanian (JKAGRI) melanggar asumsi normalitas. Hal ini dapat dilihat melalui probabilitas Jarque-Bera yang signifikan, yakni p-value sebesar 0,0028 lebih kecil dibandingkan $\alpha=5 \%$ atau dengan kata lain tolak $\mathrm{H}_{0}$ sehingga dapat disimpulkan bahwa data tidak berdistribusi multivariat normal.

\section{KESIMPULAN}

Perkembangan harga saham sektoral BEI mengalami perbedaan pola pergerakan pada saat sebelum dan sesudah merebaknya pandemi Covid-19. Sebelum merebaknya pandemi Covid-19 perkembangan harga saham sektoral menunjukkan tren peningkatan merayap dan cenderung konstan. Sedangkan, sesudah merebaknya pandemi Covid-19 perkembangan harga saham sektoral tersebut menunjukkan penurunan drastis, namun di beberapa bulan berikutnya harga saham sektoral mulai mengalami peningkatan, meskipun nilainya masih lebih rendah jika dibandingkan sebelum merebaknya pandemi Covid-19.

Berdasarkan hasil analisis VECM, variabel harga emas dalam jangka panjang berpengaruh signifikan hampir di seluruh harga saham sektoral, kecuali saham sektor pertanian dan sektor infrastruktur. Sedangkan, dalam jangka pendek berpengaruh signifikan di seluruh harga saham sektoral, kecuali saham sektor pertanian. 
Variabel harga minyak dunia dalam jangka panjang dan pendek tidak berpengaruh signifikan bagi saham sektor properti dan sektor infrastruktur, tidak berpengaruh signifikan bagi saham sektor keuangan dalam jangka panjang saja, dan tidak berpengaruh signifikan bagi saham sektor industri dasar dan kimia dalam jangka pendek saja. Variabel kurs rupiah dalam jangka panjang berpengaruh signifikan bagi saham sektor aneka industri, sektor infrastruktur, dan sektor keuangan. Sedangkan, dalam jangka pendek, variabel kurs rupiah berpengaruh signifikan hanya pada saham sektor pertanian. Kemudian, perbedaan kondisi sebelum dan sesudah merebaknya pandemi Covid-19 yang diproksikan dengan variabel dummy memberikan pengaruh signifikan bagi seluruh saham sektoral BEI.

Penerapan analisis VECM belum mampu secara tepat untuk meneliti pengaruh harga emas, harga minyak dunia, dan kurs rupiah terhadap harga saham kesembilan sektor BEI. Ditemukan beberapa persamaan yang memiliki probabilitas F-statistik tidak signifikan dan/atau koefisien ECT tidak signifikan yakni saham sektor pertambangan, sektor perdagangan, dan sektor aneka industri. Proses ketidakseimbangan jangka pendek menuju keseimbangan jangka panjang yang ditandai dengan koefisien ECT signifikan dan bernilai negatif hanya terjadi pada harga saham sektor properti, sektor infrastruktur, dan sektor keuangan. Sedangkan, jika berdasarkan perhitungan MAPE, persamaan VECM pada setiap saham sektoral memiliki akurasi yang tinggi (sangat akurat) terhadap nilai aktualnya.

\section{DAFTAR PUSTAKA}

Badan Pusat Statistik (2020). Pertumbuhan Ekonomi Indonesia Triwulan II-2020. Berita Resmi Statistik No.64/08/Th.XXIII, 5 Agustus 2020. Jakarta: Author.

Fawzi, Hasan (2020, 28 Juli). 2022, IHSG Diproyeksikan Mulai Bergerak Normal. Investor.id.

Handiani, Sylvia. (2014). Pengaruh Harga Emas Dunia, Harga Minyak Dunia Dan Nilai Tukar Dolar Amerika/Rupiah Terhadap Indeks Harga Saham Gabungan Pada Periode 2008-2013. E-Journal Graduate Unpar, 1(1). ISSN: 2355-4304.

Hilmi, Fahri. (2020, 12 Maret). OJK Jelaskan Tiga Faktor Penyebab Pasar Modal Tertekan. Republika.co.id. Juanda, B., \& Junaidi, J. (2012). Ekonometrika Deret Waktu: Teori Dan Aplikasi. Bogor: Penerbit IPB Press.

Kurniawan, Y. J. (2013). Analisis Pengaruh Tingkat Suku Bunga SBI, Inflasi, Harga Minyak Dunia, Harga Emas Dunia, Kurs Rupiah terhadap Dollar Amerika, Indeks Nikkei 225, dan Indeks Dow Jones terhadap Indeks Harga Saham Gabungan. Jurnal Ilmiah.

Lee, K. Y. M., Jais, M., \& Chan, C. W. (2020). Impact of covid-19: Evidence From Malaysian Stock Market. International Journal of Business and Society, 21(2), 607-628.

Lütkepohl, H. (2005). New Introduction to Multiple Time Series Analysis. Berlin: Springer-Verlag.

Makridakis, S., S. Wheelwright, R. Hyndman, \& Y. Chang. (1998). Forecasting Methods and Applications. 3rd ed. New York: John Wiley \& Sons.

Moreno, J.J.M., Pol, A.P., Abad, A.S., \& Blasco, B.C. (2013). Using The R-MAPE Index as a Resistant Measure of Forecast Accuracy. Psicothema. 25(4), 500-506.

Pradhypta, I. C., Iskandar, D., \& Tarumingkeng, R. C. (2018). Analisis Faktor Faktor Yang Mempengaruhi Indeks Harga Saham Gabungan Di Bursa Efek Indonesia. Jurnal Manajemen Bisnis, 13(1), 43-56.

Salim, J. F., Jamal, A., \& Seftarita, C. (2017). Pengaruh Faktor Dalam dan Luar Negeri Terhadap Indeks Harga Saham Gabungan (IHSG) di Indonesia. Jurnal Ekonomi dan Kebijakan Publik Indonesia, 4(1), 35-48.

Sirucek, Martin. (2012). Macroeconomic variables and stock market: US review. International Journal of Computer Science and Management Studies.

Sofyani, N. W., \& Wahyudi, S. (2016). Analisis Pengaruh Variabel Makro Ekonomi Global Dan Makro Ekonomi Domestik Terhadap Indeks Harga Saham Sektor Properti Dan Real Estate Dengan Metode GARCH (Periode Januari 2004-Desember 2014). Diponegoro Journal of Management, 286-299.

Witjaksono, A. A. (2010). Analisis Pengaruh Tingkat Suku Bunga SBI, Harga Minyak Dunia, Harga Emas Dunia, Kurs Rupiah, Indeks Nikkei 225, dan Indeks Dow Jones terhadap IHSG (studi kasus pada IHSG di BEI selama periode 2000-2009) (Doctoral dissertation, Universitas Diponegoro). 